\title{
Synthesis, Structure, and Reactivity of $\beta$-Diketiminate Complexes of
}

\section{Manganese(II)}

Jianfang Chai, Hongping Zhu, Herbert W. Roesky, ${ }^{*}$ Cheng He, Hans-Georg Schmidt, and Mathias Noltemeyer

Institut für Anorganische Chemie der Universität Göttingen, Tammannstrasse 4, D-37077 Göttingen, Germany

Reaction of the $\beta$-diketiminate lithium salt $\mathrm{LLi}\left(\mathrm{OEt}_{2}\right)(\mathbf{1})\left(\mathrm{L}=\mathrm{HC}(\mathrm{CMeNAr})_{2}, \mathrm{Ar}=2,6\right.$ $\left.i \mathrm{Pr}_{2} \mathrm{C}_{6} \mathrm{H}_{3}\right)$ with $\mathrm{MnCl}_{2}$ in diethyl ether provided the metalate complex $\mathrm{LMn}(\mu-\mathrm{Cl})_{2} \mathrm{Li}\left(\mathrm{OEt}_{2}\right)_{2}$ (3) in high yield. The dimeric compound $[\operatorname{LMn}(\mu-\mathrm{Cl})]_{2}(4)$ free of alkaline salt was obtained when the $\beta$-diketiminate potassium salt LK (2) was used instead of $\mathbf{1}$. The substitution reactions of 4 with $\mathrm{CpNa}, \mathrm{MeLi}$, and $\mathrm{PhLi}$ resulted in the formation of organomanganese complexes $\mathrm{LMnCp}(\mathrm{THF})(\mathbf{7}),[\mathrm{LMn}(\mu-\mathrm{Me})]_{2}(\mathbf{8})$, and $\mathrm{LMnPh}(\mathbf{9})$, respectively. The novel ionic compound $\left[\mathrm{LMnCl}_{2}\right]\left[\{\mathrm{C}(\mathrm{Me}) \mathrm{N}(i \mathrm{Pr})\}_{2} \mathrm{CH}\right](\mathbf{6})$ was obtained, when the N-heterocyclic carbene $\{\mathrm{C}(\mathrm{Me}) \mathrm{N}(i \mathrm{Pr})\}_{2} \mathrm{C}$ was used as a proton acceptor. The first doubly carboxylatobridged complex with four-coordinate manganese(II) $\left[\mathrm{LMn}\left(\mu-\mathrm{O}_{2} \mathrm{CMe}\right)\right]_{2}(\mathbf{5})$ was synthesized from the reaction of 2 and $\mathrm{Mn}\left(\mathrm{O}_{2} \mathrm{CMe}\right)_{2}$ in THF. Complexes 3-7 were characterized by single-crystal X-ray structural analysis. The structures show that the $\beta$-diketiminate ligand backbone is essentially planar and the metal centers reside in distorted tetrahedral geometry.

\footnotetext{
* To whom correspondence should be addressed. E-mail: hroesky@gwdg.de
} 


\section{Introduction}

In the past few years there is increasing interest in the $\beta$-diketiminate ligands, especially those with bulky aryl groups at the nitrogen, which have excellent steric and electronic properties to stabilize unusual complexes. ${ }^{1}$ A variety of main group element, transition metal and lanthanide complexes containing such ligands have been synthesized and characterized, some of which have novel structures and good catalytic activities. ${ }^{1}$ For example, the first monomeric $\mathrm{Al}(\mathrm{I})$ compound $\mathrm{LAl}\left(\mathrm{L}=\mathrm{HC}(\mathrm{CMeNAr})_{2}, \mathrm{Ar}=2,6-i \mathrm{Pr}_{2} \mathrm{C}_{6} \mathrm{H}_{3}\right)$ as a stable carbene analogue was synthesized in our group. ${ }^{2}$ Very recently, the aluminium dihydroxide with terminal $\mathrm{OH}$ groups and the first terminal hydroxide containing alumoxane were also obtained using the same bulky $\beta$-diketiminate ligand. ${ }^{3}$

Manganese complexes are important since they are involved in many natural processes, such as decomposition of peroxide and water oxidation of the photosystem II. $^{4}$ In view of this, it was of interest to assemble manganese complexes and explore their reactivity. In spite of the impressive results obtained by using $\beta$-diketiminate ligands now known, little work has appeared of manganese $\beta$-diketiminate complexes. Chlorides are normally the most common and cheap source of manganese(II), however, manganese chlorides containing $\beta$-diketiminate ligands remain rare prior to this work. There are only several reports on well-characterized manganese complexes containing $\beta$-diketiminate ligands in the literature. Power et al. prepared manganese silylamide $\mathrm{LMnN}\left(\mathrm{SiMe}_{3}\right)_{2}$ using $\mathrm{Mn}\left[\mathrm{N}\left(\mathrm{SiMe}_{3}\right)_{2}\right]_{2}$, which has a threecoordinate manganese center. ${ }^{5}$ Two homoleptic manganese $\beta$-diketiminate complexes were formed when less bulky ligands were employed. ${ }^{1,6}$ Recently we have synthesized some manganese iodides and their derivatives by taking advantage of anhydrous $\mathrm{MnI}_{2}$ as starting material. ${ }^{7}$ Some interesting results have been obtained, for example, the first complex with three-coordinate manganese(I) $[\mathrm{LMn}]_{2}$ containing a reactive $\mathrm{Mn}-\mathrm{Mn}$ bond has been

successfully synthesized by reduction of the iodide $[\operatorname{LMn}(\mu-\mathrm{I})]_{2} .{ }^{8}$ Herein, we report on facile 
available $\mathrm{MnCl}_{2}$ as starting material and describe the synthesis and structural characterization of a series of neutral and ionic manganese(II) chlorides $\operatorname{LMn}(\mu-\mathrm{Cl})_{2} \operatorname{Li}\left(\mathrm{OEt}_{2}\right)_{2}(3),[\mathrm{LMn}(\mu-$ $\mathrm{Cl})]_{2}(4)$, and $\left[\mathrm{LMnCl}_{2}\right]^{-}\left[\{\mathrm{C}(\mathrm{Me}) \mathrm{N}(i \mathrm{Pr})\}_{2} \mathrm{CH}\right]^{+}$(6) supported by the same bulky ligand and the resulting organomanganese derivatives $\mathrm{LMnCp}(\mathrm{THF})(\mathbf{7}),[\mathrm{LMn}(\mu-\mathrm{Me})]_{2}(\mathbf{8})$, and $\mathrm{LMnPh}(\mathbf{9})$. In addition, we also report on the first doubly carboxylato-bridged complex with fourcoordinate manganese(II) of composition $\left[\mathrm{LMn}\left(\mu-\mathrm{O}_{2} \mathrm{CMe}\right)\right]_{2}(\mathbf{5})$.

\section{Results and Discussion}

Synthesis of Compounds 3-9. The $\beta$-diketiminate lithium salt $\mathrm{LLi}\left(\mathrm{OEt}_{2}\right)$ (1) $(\mathrm{L}=$ $\left.\mathrm{HC}(\mathrm{CMeNAr})_{2}, \mathrm{Ar}=2,6-i \mathrm{Pr}_{2} \mathrm{C}_{6} \mathrm{H}_{3}\right)$ has been reported previously and widely used as metathesis reagent. ${ }^{9}$ The reaction of $\mathbf{1}$ and anhydrous $\mathrm{MnCl}_{2}$ in diethyl ether afforded the metalate complex $\mathrm{LMn}(\mu-\mathrm{Cl})_{2} \mathrm{Li}\left(\mathrm{OEt}_{2}\right)_{2}(3)$ in high yield (Scheme 1). Attempts to remove the coordinated lithium salt from the manganese center were unsuccessful. According to the experiences of preparing manganese iodides free of lithium salt, ${ }^{7 b}$ we investigated the reaction of $\mathrm{MnCl}_{2}$ with the potassium salt LK (2) instead. As expected, the dimeric compound $[\operatorname{LMn}(\mu-\mathrm{Cl})]_{2}(4)$ free of the coordinated salt was obtained in high yield (Scheme 2). Attempts to prepare the bis( $\beta$-diketiminate) complex by using 2 equiv of $\mathbf{1}$ or $\mathbf{2}$ were unsuccessful.

Dinuclear manganese complexes bridged by carboxylate groups have attracted great attention since such systems are known to exist at the active centers of some manganesecontaining enzymes. ${ }^{10}$ So it is of interest to model the coordination environment of the manganese centers in such enzymes. The doubly carboxylato-bridged complex $[\operatorname{LMn}(\mu-$ $\left.\left.\mathrm{O}_{2} \mathrm{CMe}\right)\right]_{2}$ (5) was prepared from 2 and $\mathrm{Mn}\left(\mathrm{O}_{2} \mathrm{CMe}\right)_{2}$ in THF in good yield. Crystals of 5 suitable for X-ray structural analysis were obtained by recrystallization from THF.

$\mathrm{N}-H e t e r o c y c l i c$ carbenes have been widely used as neutral and two electron donor ligands, however, the investigation of their basicities is rare. ${ }^{11}$ We are interested using the $\mathrm{N}$ - 
heterocyclic carbene as the acceptor for the proton of LH. The novel ionic compound $\left[\mathrm{LMnCl}_{2}\right]^{-}\left[\{\mathrm{C}(\mathrm{Me}) \mathrm{N}(\mathrm{iPr})\}_{2} \mathrm{CH}\right]^{+}(\mathbf{6})$ was easily obtained as a yellow crystalline solid in high yield from the reaction of $\mathrm{LH}, \mathrm{MnCl}_{2}(\mathrm{THF})_{1.5}$, and $\{\mathrm{C}(\mathrm{Me}) \mathrm{N}(i \mathrm{Pr})\}_{2} \mathrm{C}$ in $\mathrm{THF}$ at room temperature. However, no reaction occurs when in either case $\mathrm{LH}$ and $\{\mathrm{C}(\mathrm{Me}) \mathrm{N}(i \mathrm{Pr})\}_{2} \mathrm{C}$ or $\mathrm{LH}$ and $\mathrm{MnCl}_{2}(\mathrm{THF})_{1.5}$ were mixed in THF at room temperature. Therefore we suppose that the process for the formation of $\mathbf{6}$ is a concerted one and may proceed through the intermediate 6a (Scheme 3).

The substitution reactions of $\mathbf{4}$ with some nucleophiles were investigated in order to prepare organomanganese(II) complexes. Treatment of $\mathbf{4}$ with $\mathrm{CpNa}, \mathrm{MeLi}$, and $\mathrm{PhLi}$ resulted in the formation of complexes $\mathrm{LMnCp}(\mathrm{THF})(\mathbf{7}),[\mathrm{LMn}(\mu-\mathrm{Me})]_{2}(\mathbf{8})$, and $\mathrm{LMnPh}(\mathbf{9})$, respectively. The monocyclopentadienyl manganese(II) compound 7 was readily prepared as yellow crystals from the reaction of $\mathbf{4}$ and 2 equiv of $\mathrm{CpNa}$ in THF in high yield. Compound $\mathbf{7}$ is a rare example of a half-sandwich manganese(II) complex with the metal center of 17 valence electrons. ${ }^{12}$ Complexes 8 and 9 have been prepared from the reaction of $[\operatorname{LMn}(\mu-\mathrm{I})]_{2}$ with MeLi and $\mathrm{PhLi}$, respectively. ${ }^{7 \mathrm{c}}$ Compared with the substitution reactions of the iodide, the reactions of 4 with $\mathrm{MeLi}$ and $\mathrm{PhLi}$ are similar except the yields are a little lower. Complexes of manganese with variable oxidation states are of wide interest owing to their significance for biological systems. ${ }^{4 c, 13}$ Thus, the oxidation reaction of $\mathbf{4}$ was examined in order to obtain high oxidation state manganese complexes. However, the efforts to oxidize 4 with $\mathrm{I}_{2}, \mathrm{~S}$, or $\mathrm{O}_{2}$ all resulted in the decomposition of 4 .

Complexes 3-7 are yellow crystalline solids and soluble in THF. These complexes were characterized by elemental analyses, EI-MS and IR. EI-MS of $\mathbf{3}$ shows that the molecular ion peak is silent rather $[\mathrm{LMnCl}]^{+}$appears as the most intense ion at $\mathrm{m} / \mathrm{z} 507$ without the coordinated lithium salt. The molecular ion peaks of the dimeric complexes $\mathbf{4}$ and $\mathbf{5}$ in the mass spectrum are not observed, whereas half of the molecular mass $[1 / 2 \mathrm{M}]^{+}$appeared at $\mathrm{m} / \mathrm{z}$ 507 and 531 as the most intense peak, respectively. Interestingly, the ion $[\mathrm{M}-\mathrm{H}]^{+}$in the mass 
spectrum of 6 can be seen albeit with low intensity $(\mathrm{m} / \mathrm{z}, 723,2 \%)$, followed by $[\mathrm{LMnCl}]^{+} \mathrm{m} / \mathrm{z}$ $507(43 \%)$ and $\left[\{\mathrm{C}(\mathrm{Me}) \mathrm{N}(i \mathrm{Pr})\}_{2} \mathrm{CH}\right]^{+} 181(52 \%)$. In the EI-MS of 7, [LMnCp $]^{+}$appears at $m / z 537$ as the most intense ion without the coordinated solvent, followed by $m / z 472[\mathrm{M}-\mathrm{Cp}]^{+}$ (92\%). The IR spectrum of 5 displays the prominent vibrations for the O-C-O part of the bridging acetate group $v_{\mathrm{as}}\left(1602 \mathrm{~cm}^{-1}\right)$ and $v_{\mathrm{s}}\left(1437 \mathrm{~cm}^{-1}\right)$.

X-Ray Solid-state Structural Analysis. Complexes 3-7 were characterized by singlecrystal X-ray diffraction. Crystallographic data are given in Table 1 and selected bond lengths and angles in Table 2.

The X-ray structural analyses reveal that $\operatorname{LMn}(\mu-\mathrm{Cl})_{2} \operatorname{Li}\left(\mathrm{OEt}_{2}\right)_{2}(3)$ is monomeric and $[\mathrm{LMn}(\mu-\mathrm{Cl})]_{2}$ (4) dimeric in the solid state (Figures 1-2). [LMnCl$\left.{ }_{2}\right]\left[\{\mathrm{C}(\mathrm{Me}) \mathrm{N}(\mathrm{iPr})\}_{2} \mathrm{CH}\right](\mathbf{6})$ crystallizes as separated monomeric anions $\left[\mathrm{LMnCl}_{2}\right]^{-}$and cations $\left[\{\mathrm{C}(\mathrm{Me}) \mathrm{N}(i \mathrm{Pr})\}_{2} \mathrm{CH}\right]^{+}$. The structure of the anion is given in Figure 4. In these three compounds each manganese center is bound to two nitrogen atoms of the chelating ligand and two chlorine atoms in a distorted tetrahedral geometry. The backbone of the chelating ligand is nearly planar and the manganese atoms in these compounds are always out of the $\mathrm{C}_{3} \mathrm{~N}_{2}$ planes $(0.45 \AA$ in $3,0.47 \AA$ in 4, and $0.70 \AA$ in 6). The N-Mn-N angle in $6\left(91.6^{\circ}\right)$ is a little smaller than the corresponding angles in $3\left(92.2^{\circ}\right)$ and $4\left(92.8^{\circ}\right)$, and the Mn-N bond lengths in 6 (av $2.11 \AA$ ) are longer than those in $\mathbf{3}$ (av $2.08 \AA$ ) and $\mathbf{4}$ (av $2.08 \AA$ ), which indicates that the metal center in 6 is more weakly bonded to the chelating ligand due to the two terminal $\mathrm{Mn}-\mathrm{Cl}$ bonds. The average value of the terminal $\mathrm{Mn}-\mathrm{Cl}$ distance (av $2.36 \AA$ ) in $\mathbf{6}$ is comparable to those of the bridging $\mathrm{Mn}-\mathrm{Cl}$ distances in 3 (av $2.38 \AA$ ) and 4 (av $2.33 \AA$ ) due to the anion character of the $\left[\mathrm{LMnCl}_{2}\right]^{-}$in 6 . Accordingly, the $\mathrm{Cl}-\mathrm{Mn}-\mathrm{Cl}$ angle in $6\left(112.0^{\circ}\right)$ is significantly larger than those in $\mathbf{3}\left(96.2^{\circ}\right)$ and $\mathbf{4}\left(90.5^{\circ}\right)$.

The lithium atom in $\mathbf{3}$ is connected by two bridging chlorides and two oxygen atoms of two coordinated ether molecules in a distorted tetrahedral geometry. The structure is like that of 
the alkali metal adducts of the $\beta$-diketiminate metal complexes of general formula $\mathrm{L}$ 'M $(\mu$ $\mathrm{X})_{2} \mathrm{Li}(\text { ether })_{2}\left(\mathrm{~L}^{\prime}=\beta\right.$-diketiminate ligand; $\left.\mathrm{X}=\mathrm{Cl}, \mathrm{I}\right){ }^{5,7 \mathrm{a}, 14}$ The $\mathrm{Li}-\mathrm{Cl}$ and Li-O distances (av 2.38 and $1.96 \AA$, respectively) are similar to those found in $\mathrm{LM}(\mu-\mathrm{Cl})_{2} \mathrm{Li}(\mathrm{THF})_{2}(\mathrm{M}=\mathrm{Fe}(\mathrm{II})$, $\operatorname{Co}(\mathrm{II}))^{5,14}$

The central core of 4 contains an ideal planar four-membered $\mathrm{Mn}_{2} \mathrm{Cl}_{2}$ ring, which bisects and is perpendicular $\left(89.2^{\circ}\right)$ to the two chelating ligands around them. The distance between two manganese atoms is $3.28 \AA$, which can be compared to that in $[\operatorname{LMn}(\mu-\mathrm{I})]_{2}(3.62 \AA)^{7 \mathrm{~b}}$ and is out of the range of a Mn-Mn bond. The structure of the cation $\left[\{\mathrm{C}(\mathrm{Me}) \mathrm{N}(i \mathrm{Pr})\}_{2} \mathrm{CH}\right]^{+}$in 6 is similar to that in $\left[\{\mathrm{C}(\mathrm{Me}) \mathrm{N}(\mathrm{Me})\}_{2} \mathrm{CH}\right]^{+}\left[\mathrm{Ph}_{5} \mathrm{C}_{5}\right]^{-11}$.

Compound 5 crystallizes in the monoclinic space group $P 2_{1} / n$ with four molecules per unit cell. The structure of $\mathbf{5}$ is shown in Figure 3. The central manganese atoms are bonded to two nitrogen atoms each from the chelating ligands and two oxygen atoms from the two bridging acetates in a distorted tetrahedral fashion. To the best of our knowledge, compound $\mathbf{5}$ is the first example of a doubly carboxylato-bridged complex with four-coordinate manganese(II). Similar to complexes $\mathbf{3}, \mathbf{4}$, and $\mathbf{6}$, the manganese atoms are out of the chelating ligand plane (av $0.64 \AA$ ). Complex 5 contains two peripheral six-membered $\mathrm{C}_{3} \mathrm{~N}_{2} \mathrm{Mn}$ rings and one central eight-membered $\mathrm{C}_{2} \mathrm{Mn}_{2} \mathrm{O}_{4}$ macrocycle. The six- and eight-membered rings are nearly orthogonal to each other as shown by a dihedral angle of $85.8^{\circ}$.

The two acetates are in the bidentate $\mu_{1,3}$ syn-syn bridging mode, which is rare in the doubly carboxylato-bridged manganese(II) complexes. ${ }^{10}$ The Mn-O distances (av $2.01 \AA$ ) for the acetato bridges in 5 compare well with those [2.00-2.24 $\AA$ ] observed in the manganese complexes adopting the same $\mu_{1,3}$ mode. ${ }^{15}$ The non-bonding intermolecular Mn-Mn distance is $4.32 \AA$, which is in the normal range [4.15-4.79 $\AA$ ] of those found in comparable manganese(II) complexes. ${ }^{10}$ The Mn-N distance (av 2.08 $\AA$ ) and the N-Mn-N angle $\left(90.9^{\circ}\right.$ ) in $\mathbf{5}$ can be compared with those observed in $\mathbf{3}$ and $\mathbf{4}$. 
Compound $\mathbf{7}$ is monomeric with a $\mathrm{Cp}$ coordinated to the manganese center and crystallizes in the orthorhombic space group $P 2{ }_{1} 2_{1} 2_{1}$. The metal center is of pseudotetrahedral geometry surrounded by the cyclopentadienyl ring, the oxygen atom of the coordinated THF and two nitrogen atoms of the chelating ligand. The Mn-C distances [2.42-2.58 $\mathrm{A}]$ are consistent with those found in $\left[\mathrm{MeC}_{5} \mathrm{H}_{4} \mathrm{MnPEt}_{3}(\mu-\mathrm{X})\right]_{2} \quad(\mathrm{X}=\mathrm{Cl}, \quad \mathrm{Br}, \quad \mathrm{I}) \quad\left[\begin{array}{ll}2.40-2.63 \AA & \AA\end{array}\right]^{12}$ and CpMnTMEDA $\left(\eta^{1}-\mathrm{Cp}\right)[2.44-2.57 \AA] .{ }^{16}$ The Mn-N distance (av 2.13 $\AA$ ) in 7 is the longest and the N-Mn-N angle $(90.3)^{\circ}$ is the smallest among those in complexes 3-7, which is in agreement with the higher coordination number of manganese. The $\mathrm{Cp}$, the ligand plane and THF plane are nearly orthogonal to each other.

\section{Conclusion}

In summary, we have synthesized a series of neutral and ionic manganese(II) chlorides (3, 4, and 6) by using the bulky $\beta$-diketiminate ligand $\left[\mathrm{HC}(\mathrm{CMeNAr})_{2}\right]$. The reactivity of compound 4 was investigated. The substitution reactions of 4 with $\mathrm{CpNa}, \mathrm{MeLi}$, and $\mathrm{PhLi}$ afforded organomanganese complexes 7-9, respectively. In addition, we also report on the first doubly carboxylato-bridged complex $\mathbf{5}$ with four-coordinate manganese(II). Further studies on the chemistry of these complexes including oxidation reactions of $\mathbf{4}$ are in progress.

\section{Experimental Section}

General: All reactions were performed using standard Schlenk and dry box techniques. Solvents were appropriately dried and distilled under dinitrogen prior to use. Elemental analyses were performed by the Analytisches Labor des Instituts für Anorganische Chemie der Universität Göttingen. Mass spectra were obtained on a Finnigan Mat 8230. IR spectra were recorded on a Bio-Rad Digilab FTS-7 spectrometer as Nujol mulls between KBr plates.

$\mathrm{LH}_{,}{ }^{17} \mathrm{LLi}\left(\mathrm{OEt}_{2}\right) \quad(\mathbf{1}),{ }^{9} \quad \mathrm{LK} \quad(\mathbf{2}),{ }^{7 \mathrm{~b}} \quad\left(\mathrm{~L}=\mathrm{HC}(\mathrm{CMeNAr})_{2}, \quad \mathrm{Ar}=2,6-i \mathrm{Pr}_{2} \mathrm{C}_{6} \mathrm{H}_{3}\right)$ and $\{\mathrm{C}(\mathrm{Me}) \mathrm{N}(i \mathrm{Pr})\}_{2} \mathrm{C}^{18}$ were prepared by literature procedures. $\left.\underline{\mathrm{Mn}\left(\mathrm{O}_{2}\right.} \underline{\mathrm{CMe}}\right)_{2} \underline{2}$ was purchased from Aldrich and used without purification. Anhydrous $\mathrm{MnCl}_{2}$ was obtained by dehydration of 
$\mathrm{MnCl}_{2}\left(\mathrm{H}_{2} \underline{\mathrm{O}}\right)_{4} \cdot{ }^{19} \mathrm{MnCl}_{2}(\mathrm{THF})_{\underline{1.5}}$ was synthesized as described in the literature. ${ }^{20}$ The syntheses of complexes 8 and 9 are similar to those of [7c]. NMR spectra of complexes 3-9 are not available due to the paramagnetic nature of manganese(II).

$\mathbf{L M n}(\mu-\mathbf{C l})_{2} \mathbf{L i}\left(\mathbf{O E t}_{2}\right)_{2}(3) \mathrm{LLi}\left(\mathrm{OEt}_{2}\right)(1.0 \mathrm{~g}, 2 \mathrm{mmol})$ in diethyl ether $(15 \mathrm{~mL})$ was added to a suspension of $\mathrm{MnCl}_{2}(0.25 \mathrm{~g}, 2 \mathrm{mmol})$ in diethyl ether $(40 \mathrm{~mL})$ at $-78{ }^{\circ} \mathrm{C}$. The mixture was warmed to $\mathrm{rt}$ and stirred for $14 \mathrm{~h}$. The resulting precipitate was removed by filtration. The solution was concentrated to ca. $10 \mathrm{~mL}$. Yellow crystals were obtained after $2 \mathrm{~d}$ at $-26{ }^{\circ} \mathrm{C}$. Yield: $1.13 \mathrm{~g}(81 \%)$. Mp: $>270{ }^{\circ} \mathrm{C}$ (dec). Anal. Calcd for $\mathrm{C}_{37} \mathrm{H}_{61} \mathrm{Cl}_{2} \mathrm{LiMnN}_{2} \mathrm{O}_{2}$ (698.66): $\mathrm{C}$, 63.55; H, 8.73; N, 4.01. Found: $\underline{\mathrm{C}, 63.13 ; \mathrm{H}, 8.54 ; \mathrm{N}, 4.47 .}$ EI-MS: $\mathrm{m} / z$ (\%) 507 (100) [M$\left.\operatorname{LiCl}\left(\mathrm{OEt}_{2}\right)_{2}\right]^{+} . \mathrm{IR}\left(\mathrm{KBr}\right.$, Nujol mull, $\left.\mathrm{cm}^{-1}\right): \tilde{v}=1624(\mathrm{w}), 1539(\mathrm{w}), 1523(\mathrm{~m}), 1398(\mathrm{~m})$, 1366 (w), 1316 (m), 1262 (m), 1231 (w), $1176(\mathrm{w}), 1099$ (m), 1056 (w), 1022 (m), 934 (w), $873(w), 853(w), 795(m), 759(w), 722(w), 636(w), 600(w), 527(w), 452(w)$.

$[\mathbf{L M n}(\mu-\mathbf{C l})]_{2}(4) \mathrm{LK}(0.91 \mathrm{~g}, 2 \mathrm{mmol})$ in diethyl ether $(15 \mathrm{~mL})$ was added to a suspension of $\mathrm{MnCl}_{2}(0.25 \mathrm{~g}, 2 \mathrm{mmol})$ in diethyl ether $(40 \mathrm{~mL})$ at $-78^{\circ} \mathrm{C}$. The mixture was warmed to rt and stirred for $14 \mathrm{~h}$. The resulting precipitate was removed by filtration. The solution was concentrated to ca. $10 \mathrm{~mL}$. Yellow crystals were obtained after $1 \mathrm{~d}$ at $-26{ }^{\circ} \mathrm{C}$. Yield: $0.88 \mathrm{~g}$ (87\%). Mp: $>400{ }^{\circ} \mathrm{C}$. Anal. Calcd for $\mathrm{C}_{58} \mathrm{H}_{82} \mathrm{Cl}_{2} \mathrm{Mn}_{2} \mathrm{~N}_{4}$ (1016.06): C, 68.50; H, 8.07; N, 5.51. Found: C, 68.75; H, 8.23; N, 5.21. EI-MS: m/z (\%) 507 (100) [1/2M] $]^{+}$IR (KBr, Nujol mull, $\left.\mathrm{cm}^{-1}\right): \widetilde{v}=1656(\mathrm{w}), 1623(\mathrm{w}), 1592(\mathrm{w}), 1553(\mathrm{w}), 1528(\mathrm{w}), 1326(\mathrm{w}), 1292(\mathrm{w}), 1261(\mathrm{~m})$, $1175(\mathrm{~m}), 1098(\mathrm{~m}), 1025(\mathrm{~m}), 936(\mathrm{w}), 801(\mathrm{~m}), 758(\mathrm{w}), 722(\mathrm{w}), 664(\mathrm{w}), 618(\mathrm{w}), 541$ (w), $466(w)$.

$\left[\mathbf{L M n}\left(\boldsymbol{\mu}-\mathbf{O}_{2} \mathbf{C M e}\right)\right]_{2}(\mathbf{5}) \mathrm{LK}(0.91 \mathrm{~g}, 2 \mathrm{mmol})$ in THF $(10 \mathrm{~mL})$ was added to a suspension of $\mathrm{Mn}\left(\mathrm{O}_{2} \mathrm{CMe}\right)_{2}(0.35 \mathrm{~g}, 2 \mathrm{mmol})$ in THF $(30 \mathrm{~mL})$ at $-78{ }^{\circ} \mathrm{C}$. The mixture was warmed to $\mathrm{rt}$ and stirred for $12 \mathrm{~h}$. The resulting precipitate was removed by filtration. The solution was concentrated to ca. $5 \mathrm{~mL}$. Yellow crystals were obtained after $7 \mathrm{~d}$ at $-26{ }^{\circ} \mathrm{C}$. Mp: $>330{ }^{\circ} \mathrm{C}$ 
(dec). Yield: 0.80 g (75\%). Anal. Calcd for $\mathrm{C}_{62} \mathrm{H}_{88} \mathrm{Mn}_{2} \mathrm{~N}_{4} \mathrm{O}_{4}$ (1063.24): C, 70.00; H, 8.28; N, 5.27. Found: C, 69.68; H, 8.19; N, 5.00. EI-MS: m/z (\%) $531(100)[1 / 2 \mathrm{M}]^{+}$. IR (KBr, Nujol mull, $\left.\mathrm{cm}^{-1}\right): \tilde{v}=1602(\mathrm{~s}), 1544(\mathrm{~m}), 1519(\mathrm{~m}), 1437(\mathrm{~s}), 1380(\mathrm{~m}), 1317(\mathrm{~m}), 1262(\mathrm{w}), 1177$ (w), $1099(w), 1021(w), 933(w), 851(w), 793(w), 759(w), 643(w)$.

$\left[\mathbf{L M n C l} \mathbf{L}_{2}\right]\left[\{\mathbf{C}(\mathbf{M e}) \mathbf{N}(\mathbf{i P r})\}_{2} \mathbf{C H}\right] \quad(\mathbf{6}) \quad \mathrm{THF}(40 \mathrm{~mL})$ was added to a mixture of $\mathrm{MnCl}_{2}(\mathrm{THF})_{1.5}(0.47 \mathrm{~g}, 2 \mathrm{mmol}), \mathrm{LH}(0.83 \mathrm{~g}, 2 \mathrm{mmol})$, and $\{\mathrm{C}(\mathrm{Me}) \mathrm{N}(i \mathrm{Pr})\}_{2} \mathrm{C}(0.36 \mathrm{~g}, 2$ mmol) at rt. The resulting suspension was stirred for $12 \mathrm{~h}$ and a clear yellow solution was obtained. The solution was concentrated to ca. $10 \mathrm{~mL}$ and kept at $4{ }^{\circ} \mathrm{C}$. Yellow crystals were obtained after $3 \mathrm{~d}$. Yield: $1.23 \mathrm{~g}(85 \%)$. Mp: $>210{ }^{\circ} \mathrm{C}$ (dec). Anal. Calcd for $\mathrm{C}_{40} \mathrm{H}_{62} \mathrm{Cl}_{2} \mathrm{MnN}_{4}$ (724.78): C, 66.23; H, 8.55; N, 7.73. Found: C, 65.85; H, 8.75; N, 7.45. EI-MS: $m / z(\%) 723$ (2) $[\mathrm{M}-\mathrm{H}]^{+}, 507(43)[\mathrm{LMnCl}]^{+}, 181(52)\left[\{\mathrm{C}(\mathrm{Me}) \mathrm{N}(i \mathrm{Pr})\}_{2} \mathrm{CH}\right]^{+}$. IR (KBr, Nujol mull, $\left.\mathrm{cm}^{-1}\right)$ : $\tilde{v}=3126(\mathrm{w}), 3058(\mathrm{w}), 1663(\mathrm{w}), 1628(\mathrm{w}), 1551(\mathrm{~m}), 1542(\mathrm{~m}), 1516(\mathrm{~m}), 1438(\mathrm{~s}), 1400$ (s), 1321 (s), 1263 (s), 1232 (m), 1193 (w), 1177 (m), 1143 (w), 1101 (s), 1056 (w), 1023 (s), $962(w), 936(\mathrm{~m}), 868(\mathrm{w}), 849(\mathrm{w}), 799(\mathrm{~s}), 792(\mathrm{~s}), 764(\mathrm{~m}), 758(\mathrm{~m}), 721(\mathrm{w}), 652(\mathrm{w}), 630$ (w).

LMnCp(THF) (7) CpNa (0.6 mL, 2.0 M in THF, $1.2 \mathrm{mmol})$ was added to a solution of 4 $(0.51 \mathrm{~g}, 0.5 \mathrm{mmol})$ in THF $(20 \mathrm{~mL})$ at $-78{ }^{\circ} \mathrm{C}$. The mixture was allowed to warm to $\mathrm{rt}$ and stirred for $14 \mathrm{~h}$. All volatiles were removed in vacuum and the residue was extracted with toluene $(15 \mathrm{~mL})$. The yellow solution was concentrated to ca. $10 \mathrm{~mL}$ and kept at $\mathrm{rt}$ for $2 \mathrm{~d}$ to give yellow crystals. The crystals were collected by filtration and the filtrate was concentrated and kept at $4{ }^{\circ} \mathrm{C}$ for $7 \mathrm{~d}$ to give additional crystals. Total yield: $0.52 \mathrm{~g}$ (86\%). Mp: 210-212 ${ }^{\circ}$ C. Anal. Calcd for $\mathrm{C}_{38} \mathrm{H}_{54} \mathrm{MnN}_{2} \mathrm{O}$ (609.77): C, 74.88; H, 8.87; N, 4.60. Found: C, 74.46; H, 8.76; N, 4.64. EI-MS: $m / z(\%) 537$ (100) [M] $]^{+}, 472(92)[\mathrm{LMn}]^{+}$. IR (KBr, Nujol mull, $\left.\mathrm{cm}^{-1}\right)$ : $\widetilde{v}=1653(\mathrm{w}), 1542(\mathrm{w}), 1521(\mathrm{~m}), 1401(\mathrm{~m}), 1315(\mathrm{~m}), 1262(\mathrm{~s}), 1231(\mathrm{w}), 1172(\mathrm{w}), 1098$ (s), 1056 (m), 1028 (s), 933 (w), 872 (w), 846 (w), 793 (s), 765 (w), $751(\mathrm{~m}), 721(\mathrm{~m}), 667$ (w), $601(\mathrm{w}), 466(\mathrm{w})$. 
X-ray Crystallography: Crystallographic data for 3-6 were collected on a Stoe-SiemensHuber four-circle diffractometer coupled to a Siemens CCD area detector and for $\mathbf{7}$ on a Stoe IPDS II-array detector system. In both cases graphite-monochromated Mo- $K_{\alpha}$ radiation $(\lambda=$ $0.71073 \AA$ ) was used. All structures were solved by direct methods (SHELXS-97) ${ }^{21}$ and refined against $F^{2}$ using SHELXL-97. ${ }^{22}$ All non-hydrogen atoms were refined anisotropically. The hydrogen atoms were included at geometrically calculated positions and refined using a riding model. For compound 6, Flack $\times$ parameter $=-0.0229$ with esd 0.0382. Expected values are 0 (within 3 esd's) for correct and +1 for the inverted absolute structure. The absolute structure of 7 could not be determined and a twin refinement was done.

Acknowledgment. We are grateful to the Deutsche Forschungsgemeinschaft, the Fonds der Chemischen Industrie, and the Göttinger Akademie der Wissenschaften for support of this work.

Supplementary Material Available: X-ray structural information for complexes 3-7. This material is available free of charge via the internet at http://pubs.acs.org.

(1) Bourget-Merle, L.; Lappert, M. F.; Severn, J. R. Chem. Rev. 2002, 102, 3031.

(2) Cui, C.; Roesky, H. W.; Schmidt, H.-G.; Noltemeyer, M.; Hao, H.; Cimpoesu, F. Angew. Chem. Int. Ed. 2000, 39, 4274.

(3) (a) Bai, G.; Peng, Y.; Roesky, H. W.; Li, J.; Schmidt, H.-G.; Noltemeyer, M. Angew. Chem. Int. Ed. 2003, 42, 1132. (b) Bai, G.; Roesky, H. W.; Li, J.; Noltemeyer, M.; Schmidt, H.-G. Angew. Chem. Int. Ed. 2003, 42, 5502.

(4) (a) Hoganson, C. W.; Babcock, G. T. Science 1997, 277, 1953. (b) Sakiyama, H.; Sugawara, A.; Sakamoto, M.; Unoura, K.; Inoue, K.; Yamasaki, M. Inorg. Chim. Acta 2000, 310, 163. (c) Stubbe, J.; van der Donk, W. A. Chem. Rev. 1998, 98, 705.

(5) Panda, A.; Stender, M.; Wright, R. J.; Olmstead, M. M.; Klavins, P.; Power, P. P. Inorg. Chem. 2002, 41, 3909. 
(6) Danopoulos, A. A.; Wilkinson, G.; Sweet, T. K. N.; Hursthouse, M. B. J. Chem. Soc., Dalton Trans. 1995, 205.

(7) (a) Prust, J.; Most, K.; Müller, I.; Stasch, A.; Roesky, H. W.; Usón, I. Eur. J. Inorg. Chem. 2001, 1613. (b) Chai, J.; Zhu, H.; Most, K.; Roesky, H. W.; Vidovic, D.; Schmidt, H.-G.; Noltemeyer, M. Eur. J. Inorg. Chem. 2003, 4332. (c) Chai, J.; Zhu, H.; Fan, H.; Roesky, H. W.; Magull, J. Organometallics 2004, 23, 1177.

(8) Chai, J.; Zhu, H.; Roesky, H. W. Angew. Chem. Int. Ed. submitted.

(9) Ding, Y.; Roesky, H. W.; Noltemeyer, M.; Schmidt, H.-G.; Power, P. P. Organometallics 2001, 20, 1190.

(10) Chen, X.-M.; Tong, Y.-X.; Xu, Z.-T.; Mark, T. C. W. J. Chem. Soc., Dalton Trans. 1995, 4001 and references cited therein.

(11) Filipponi, S.; Jones, J. N.; Johnson, J. A.; Cowley, A. H.; Grepioni, F.; Braga, D. Chem. Commun. 2003, 2716.

(12) Köhler, F. H.; Hebendanz, N.; Müller, G.; Thewalt, U.; Kanellakopulos, B.; Klenze, R. Organometallics 1987, 6, 115.

(13) Ellison, J. J.; Power, P. P.; Shoner, S. C. J. Am. Chem. Soc. 1989, 111, 8044 and references cited therein.

(14) Smith, J. M.; Lachicotte, R. J.; Holland, P. L. Chem. Commun. 2001, 1542.

(15) Romero, I.; Dubois, L.; Collomb, M.-N.; Deronzier, A.; Latour, J.-M.; Pecaut, J. Inorg. Chem. 2002, 41, 1795.

(16) Heck, J.; Massa, W.; Wenig, P. Angew. Chem. Int. Ed. Engl. 1984, 23, 722.

(17) Feldman, J.; McLain, S. J.; Parthasarathy, A.; Marshall, W. J.; Calabrese, J. C.; Arthur, S. D. Organometallics 1997, 16, 1514.

(18) Kuhn, N.; Kratz, T. Synthesis 1993, 561.

(19) Horvath, B.; Moeseler, R.; Horvath, E. G. Z. Anorg. Allg. Chem. 1979, 450, 165.

(20) Kern, R. J. J. Inorg. Nucl. Chem. 1962, 24, 1105. 
(21) Sheldrick, G. M. Acta Crystallogr. Sect. A 1990, 46, 467.

(22) Sheldrick, G. M. SHELXL-97, Program for Crystal Structure Refinement, Universität Göttingen, 1997.

\section{Scheme 1}

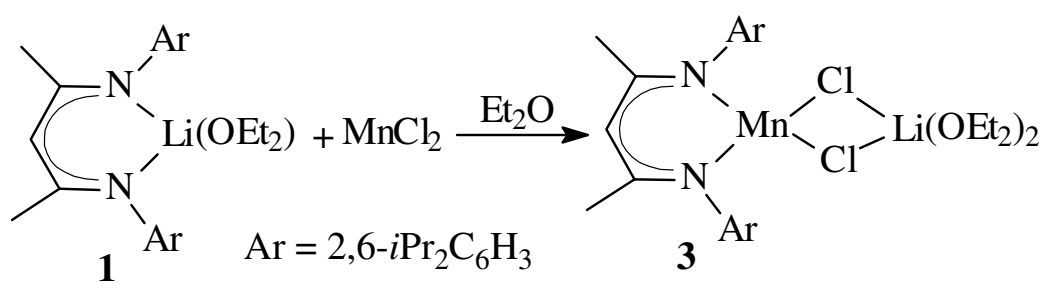

Scheme 2

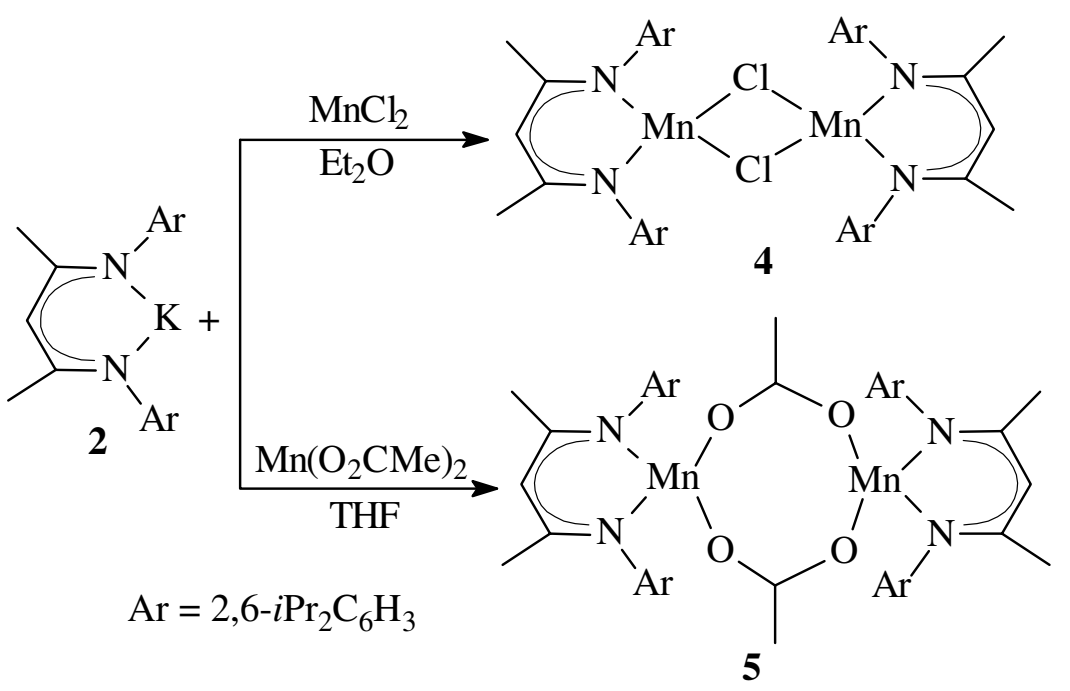




\section{Scheme 3}

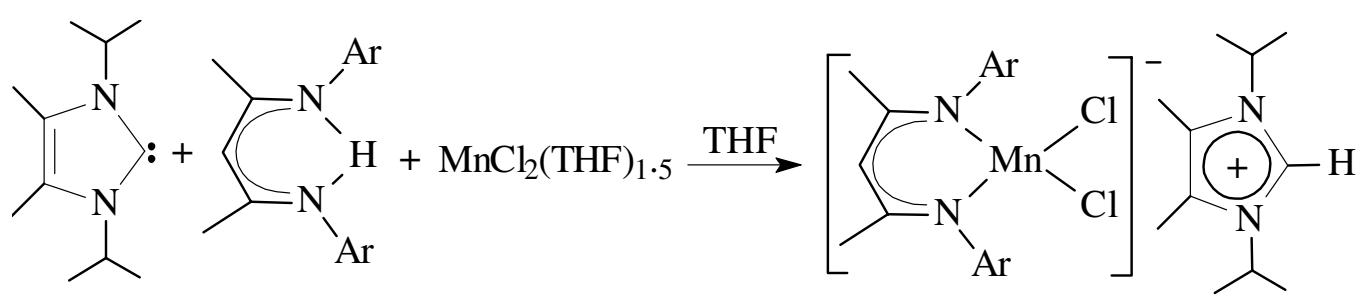

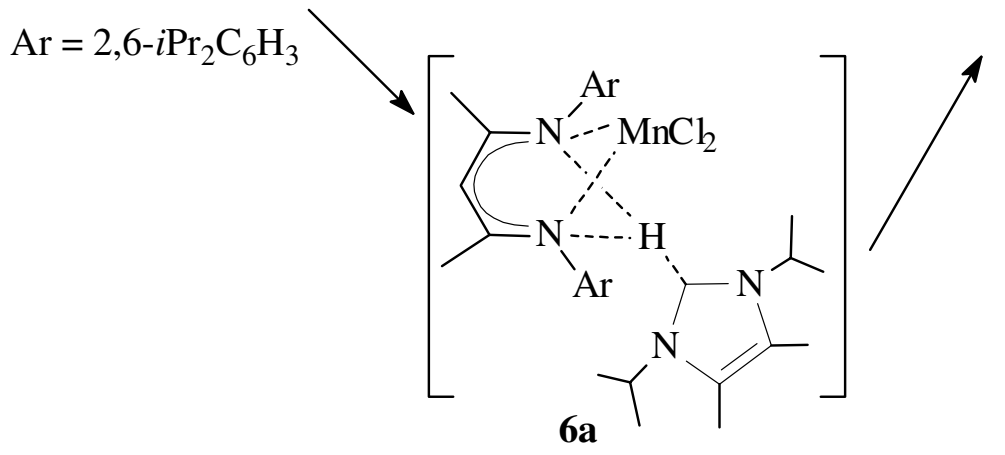

Scheme 4

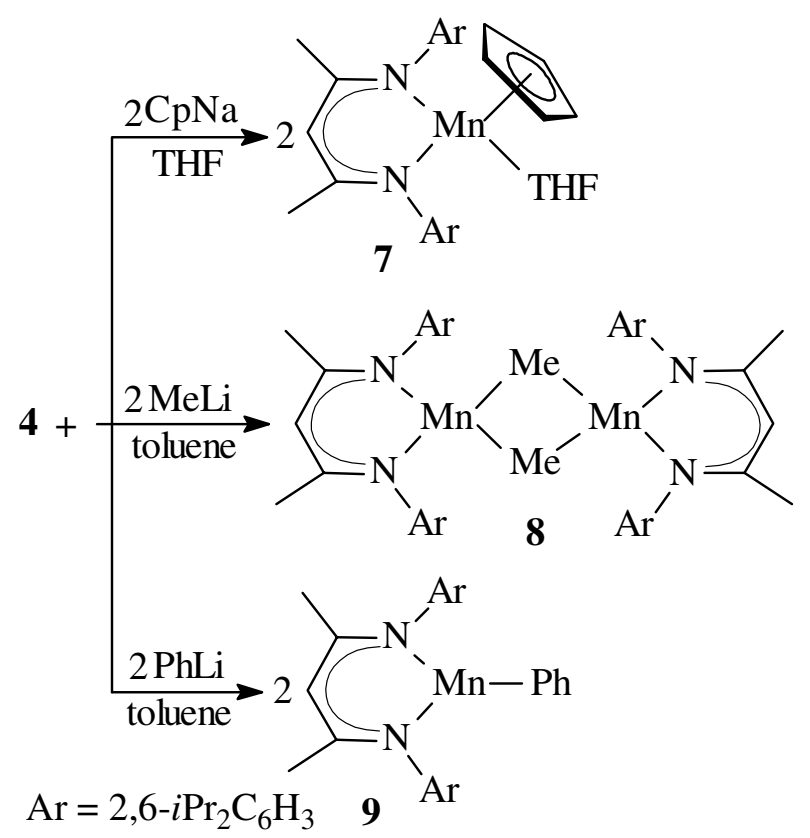


Table 1. Crystallographic data for complexes 3-7

\begin{tabular}{|c|c|c|c|c|c|}
\hline & 3 & $1 / 24$ & 5 & 6 & 7 \\
\hline \multirow[t]{2}{*}{ formula } & $\mathrm{C}_{37} \mathrm{H}_{61} \mathrm{Cl}_{2} \mathrm{Li}$ & $\mathrm{C}_{29} \mathrm{H}_{41} \mathrm{ClMn}$ & $\mathrm{C}_{62} \mathrm{H}_{88} \mathrm{Mn}_{2}$ & $\mathrm{C}_{40} \mathrm{H}_{62} \mathrm{Cl}_{2} \mathrm{MnN}_{4}$ & $\mathrm{C}_{38} \mathrm{H}_{54} \mathrm{MnN}_{2} \mathrm{O}$ \\
\hline & $\mathrm{MnN}_{2} \mathrm{O}_{2}$ & $\mathrm{~N}_{2}$ & $\mathrm{~N}_{4} \mathrm{O}_{4}$ & & \\
\hline fw & 698.66 & 508.03 & 1063.24 & 724.78 & 609.77 \\
\hline $\mathrm{T}(\mathrm{K})$ & $153(2)$ & $200(2)$ & $203(2)$ & $150(2)$ & $133(2)$ \\
\hline cryst syst & monoclinic & monoclinic & monoclinic & orthorhombic & orthorhombic \\
\hline space group & $P 2_{1} / n$ & $C 2 / c$ & $P 2_{1} / c$ & $P 2{ }_{1} 2_{1} 2_{1}$ & $P 2{ }_{1} 2_{1} 2_{1}$ \\
\hline$a(\AA)$ & $12.053(2)$ & $22.921(5)$ & $17.32(3)$ & $11.218(4)$ & $10.007(2)$ \\
\hline$b(\AA)$ & $21.327(4)$ & $14.8779(15)$ & $15.210(17)$ & $12.606(10)$ & $16.985(3)$ \\
\hline$c(\AA)$ & $15.706(3)$ & $16.291(2)$ & $23.30(3)$ & $28.93(2)$ & $20.081(4)$ \\
\hline$\alpha(\mathrm{deg})$ & 90 & 90 & 90 & 90 & 90 \\
\hline$\beta(\operatorname{deg})$ & $100.11(3)$ & $90.884(12)$ & $101.94(6)$ & 90 & 90 \\
\hline$\gamma(\mathrm{deg})$ & 90 & 90 & 90 & 90 & 90 \\
\hline$V\left(\AA^{3}\right)$ & $3974.3(14)$ & $5555.1(15)$ & $6010(2)$ & $4090(1)$ & $3413.3(12)$ \\
\hline Z & 4 & 8 & 4 & 4 & 4 \\
\hline$D_{\text {calcd }}\left(\mathrm{g} \mathrm{cm}^{-3}\right)$ & 1.168 & 1.215 & 1.176 & 1.177 & 1.187 \\
\hline$\mu\left(\mathrm{mm}^{-1}\right)$ & 0.498 & 0.590 & 0.467 & 0.484 & 0.417 \\
\hline$F(000)$ & 1500 & 2168 & 2280 & 1556 & 1316 \\
\hline cryst size & $0.90 \times 0.60 \times$ & $0.60 \times 0.40 \times$ & $0.70 \times 0.40$ & $0.60 \times 0.50 \times$ & $0.30 \times 0.30 \times$ \\
\hline$(\mathrm{mm})$ & 0.30 & 0.40 & $\times 0.30$ & 0.50 & 0.30 \\
\hline $2 \theta$ range & $7.04-50.10$ & $7.02-49.96$ & $7.06-45.00$ & $7.06-44.98$ & $3.14-49.44$ \\
\hline
\end{tabular}




\begin{tabular}{|c|c|c|c|c|c|}
\hline no. of rflns & 10312 & 7144 & 7382 & 3116 & 36246 \\
\hline \multicolumn{6}{|l|}{ collected } \\
\hline no. of indep & 6998 (R(int) & 4872 (R(int) & 7382 & $2999(R($ int $)=$ & $5798(R($ int $)=$ \\
\hline rflns & $=0.0574)$ & $=0.0307)$ & $\begin{array}{l}(R(\text { int })= \\
0.0000)\end{array}$ & 0.0745) & $0.0371)$ \\
\hline $\begin{array}{l}\text { no. of data / } \\
\text { restraints }\end{array}$ & $6998 / 0 / 420$ & $4872 / 0 / 308$ & $7382 / 0 / 671$ & 2999/0/449 & $5798 / 0 / 389$ \\
\hline /params & & & & & \\
\hline goodness-of- & 1.026 & 1.024 & 1.013 & 1.089 & 1.064 \\
\hline fit, $F^{2}$ & & & & & \\
\hline$R 1, w R 2[I>$ & 0.0505 & 0.0626 & 0.0815 & $0.0445,0.1009$ & $0.0255,0.0617$ \\
\hline $2 \sigma(I)]$ & 0.1213 & 0.1648 & 0.1843 & & \\
\hline$R 1, w R 2$ (all & 0.0636 & 0.0821 & 0.1403 & $0.0653,0.1136$ & $0.0280,0.0626$ \\
\hline data) & 0.1322 & 0.1817 & 0.2315 & & \\
\hline largest diff & 0.562 to - & 0.400 to - & 0.579 to - & 0.533 to -0.505 & 0.305 to -0.291 \\
\hline peak $\left(\mathrm{e} \AA^{-3}\right)$ & 0.634 & 1.366 & 0.721 & & \\
\hline
\end{tabular}


Table 2. Selected bond lengths ( $\mathrm{A})$ and bond angles (deg) for compounds 3-7

\begin{tabular}{|c|c|c|c|}
\hline \multicolumn{4}{|l|}{ Compound $\mathbf{3}$} \\
\hline $\mathrm{Mn}(1)-\mathrm{N}(1)$ & $2.083(2)$ & $\mathrm{N}(1)-\mathrm{Mn}(1)-\mathrm{N}(2)$ & $92.21(8)$ \\
\hline $\operatorname{Mn}(1)-N(2)$ & $2.072(2)$ & $\mathrm{N}(1)-\mathrm{Mn}(1)-\mathrm{Cl}(1)$ & $118.99(7)$ \\
\hline $\operatorname{Mn}(1)-\mathrm{Cl}(1)$ & $2.3688(11)$ & $\mathrm{N}(2)-\mathrm{Mn}(1)-\mathrm{Cl}(1)$ & $116.72(7)$ \\
\hline $\operatorname{Mn}(1)-\mathrm{Cl}(2)$ & $2.3887(10)$ & $\mathrm{Cl}(1)-\mathrm{Mn}(1)-\mathrm{Cl}(2)$ & $96.10(3)$ \\
\hline $\mathrm{Li}(1)-\mathrm{Cl}(1)$ & $2.371(5)$ & $\mathrm{N}(1)-\mathrm{Mn}(1)-\mathrm{Cl}(2)$ & $115.29(6)$ \\
\hline $\mathrm{Li}(1)-\mathrm{Cl}(2)$ & $2.383(5)$ & $\mathrm{N}(2)-\mathrm{Mn}(1)-\mathrm{Cl}(2)$ & $119.48(6)$ \\
\hline $\mathrm{Li}(1)-\mathrm{O}(1)$ & $1.948(6)$ & $\mathrm{Cl}(1)-\mathrm{Li}(1)-\mathrm{Cl}(2)$ & $96.20(17)$ \\
\hline $\mathrm{Li}(1)-\mathrm{O}(2)$ & $1.975(6)$ & $\mathrm{O}(1)-\mathrm{Li}(1)-\mathrm{O}(2)$ & $114.7(3)$ \\
\hline \multicolumn{4}{|l|}{ Compound 4} \\
\hline $\mathrm{Mn}(1)-\mathrm{N}(1)$ & $2.0830(9)$ & $\mathrm{N}(1)-\mathrm{Mn}(1)-\mathrm{N}(2)$ & $92.80(3)$ \\
\hline $\operatorname{Mn}(1)-\mathrm{N}(2)$ & $2.0819(10)$ & $\mathrm{N}(1)-\mathrm{Mn}(1)-\mathrm{Cl}(1)$ & $117.09(3)$ \\
\hline $\operatorname{Mn}(1)-\mathrm{Cl}(1)$ & $2.3422(7)$ & $\mathrm{N}(2)-\mathrm{Mn}(1)-\mathrm{Cl}(1)$ & $118.34(3)$ \\
\hline $\operatorname{Mn}(1)-\operatorname{Cl}(1 \mathrm{~A})$ & $2.3093(6)$ & $\mathrm{Cl}(1)-\mathrm{Mn}(1)-\mathrm{Cl}(1 \mathrm{~A})$ & $90.49(2)$ \\
\hline $\operatorname{Mn}(1 \mathrm{~A})-\mathrm{Cl}(1)$ & $2.3093(6)$ & $\mathrm{N}(1)-\mathrm{Mn}(1)-\mathrm{Cl}(1 \mathrm{~A})$ & $119.74(3)$ \\
\hline $\operatorname{Mn}(1)-\operatorname{Mn}(1 \mathrm{~A})$ & 3.275 & $\mathrm{~N}(2)-\mathrm{Mn}(1)-\mathrm{Cl}(1 \mathrm{~A})$ & $120.93(3)$ \\
\hline \multicolumn{4}{|l|}{ Compound $\mathbf{5}$} \\
\hline $\mathrm{Mn}(1)-\mathrm{N}(1)$ & $2.075(6)$ & $\mathrm{N}(1)-\mathrm{Mn}(1)-\mathrm{N}(2)$ & $90.9(2)$ \\
\hline $\operatorname{Mn}(1)-N(2)$ & $2.077(6)$ & $\mathrm{N}(1)-\mathrm{Mn}(1)-\mathrm{O}(1)$ & $110.9(3)$ \\
\hline $\mathrm{Mn}(1)-\mathrm{O}(1)$ & $2.014(7)$ & $\mathrm{N}(1)-\mathrm{Mn}(1)-\mathrm{O}(2)$ & $115.6(3)$ \\
\hline $\mathrm{Mn}(1)-\mathrm{O}(2)$ & $1.991(7)$ & $\mathrm{N}(2)-\mathrm{Mn}(1)-\mathrm{O}(1)$ & $110.9(3)$ \\
\hline $\operatorname{Mn}(2)-N(3)$ & $2.082(6)$ & $\mathrm{N}(2)-\mathrm{Mn}(1)-\mathrm{O}(2)$ & $112.3(3)$ \\
\hline
\end{tabular}




\begin{tabular}{|c|c|c|c|}
\hline $\operatorname{Mn}(2)-N(4)$ & $2.086(6)$ & $\mathrm{O}(1)-\mathrm{Mn}(1)-\mathrm{O}(2)$ & 114.1(3) \\
\hline $\mathrm{Mn}(2)-\mathrm{O}(3)$ & $2.012(7)$ & $\mathrm{O}(3)-\mathrm{Mn}(2)-\mathrm{O}(4)$ & $117.8(3)$ \\
\hline $\mathrm{Mn}(2)-\mathrm{O}(4)$ & $2.031(7)$ & $\mathrm{N}(3)-\mathrm{Mn}(2)-\mathrm{N}(4)$ & $92.0(2)$ \\
\hline $\operatorname{Mn}(1)-\operatorname{Mn}(2)$ & 4.319 & & \\
\hline \multicolumn{4}{|l|}{ Compound 6} \\
\hline $\mathrm{Mn}(1)-\mathrm{N}(1)$ & $2.102(2)$ & $\mathrm{N}(1)-\mathrm{Mn}(1)-\mathrm{N}(2)$ & $91.64(8)$ \\
\hline $\operatorname{Mn}(1)-\mathrm{N}(2)$ & $2.111(2)$ & $\mathrm{N}(1)-\mathrm{Mn}(1)-\mathrm{Cl}(1)$ & $107.84(6)$ \\
\hline $\mathrm{Mn}(1)-\mathrm{Cl}(1)$ & $2.3890(11)$ & $\mathrm{N}(2)-\mathrm{Mn}(1)-\mathrm{Cl}(1)$ & $109.42(7)$ \\
\hline $\mathrm{Mn}(1)-\mathrm{Cl}(2)$ & $2.3370(10)$ & $\mathrm{Cl}(1)-\mathrm{Mn}(1)-\mathrm{Cl}(2)$ & $112.00(4)$ \\
\hline \multicolumn{4}{|l|}{ Compound 7} \\
\hline $\mathrm{Mn}(1)-\mathrm{N}(1)$ & $2.1242(15)$ & $\mathrm{N}(1)-\mathrm{Mn}(1)-\mathrm{N}(2)$ & $90.26(5)$ \\
\hline $\operatorname{Mn}(1)-\mathrm{N}(2)$ & $2.1306(15)$ & $\mathrm{N}(1)-\mathrm{Mn}(1)-\mathrm{O}(31)$ & $97.69(5)$ \\
\hline $\mathrm{Mn}(1)-\mathrm{O}(31)$ & $2.2787(12)$ & $\mathrm{N}(2)-\mathrm{Mn}(1)-\mathrm{O}(31)$ & $97.60(6)$ \\
\hline $\operatorname{Mn}(1)-C(6)$ & $2.547(2)$ & $\mathrm{N}(1)-\mathrm{Mn}(1)-\mathrm{C}(6)$ & $96.96(6)$ \\
\hline $\operatorname{Mn}(1)-C(7)$ & $2.442(2)$ & $\mathrm{N}(2)-\mathrm{Mn}(1)-\mathrm{C}(6)$ & $144.79(7)$ \\
\hline $\operatorname{Mn}(1)-C(8)$ & $2.419(2)$ & $\mathrm{O}(31)-\mathrm{Mn}(1)-\mathrm{C}(6)$ & $115.34(6)$ \\
\hline $\operatorname{Mn}(1)-C(9)$ & $2.5088(19)$ & $\mathrm{N}(1)-\mathrm{Mn}(1)-\mathrm{C}(7)$ & $120.33(7)$ \\
\hline $\operatorname{Mn}(1)-C(10)$ & $2.5778(19)$ & $\mathrm{N}(2)-\mathrm{Mn}(1)-\mathrm{C}(7)$ & $147.88(7)$ \\
\hline
\end{tabular}




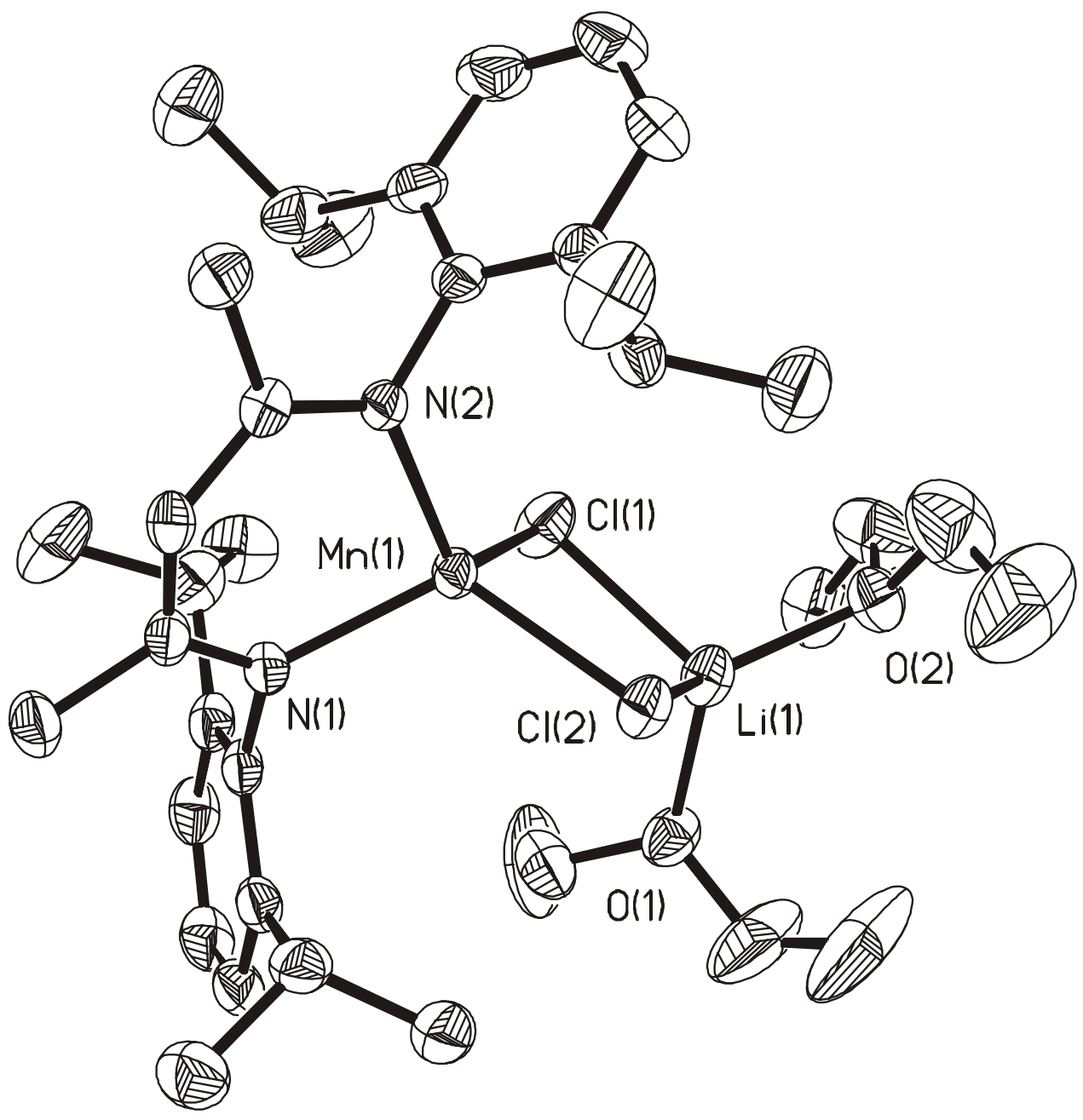

Figure 1. Molecular structure of $\mathbf{3}$ (50\% probability thermal ellipsoids). Hydrogen atoms are omitted for clarity. 


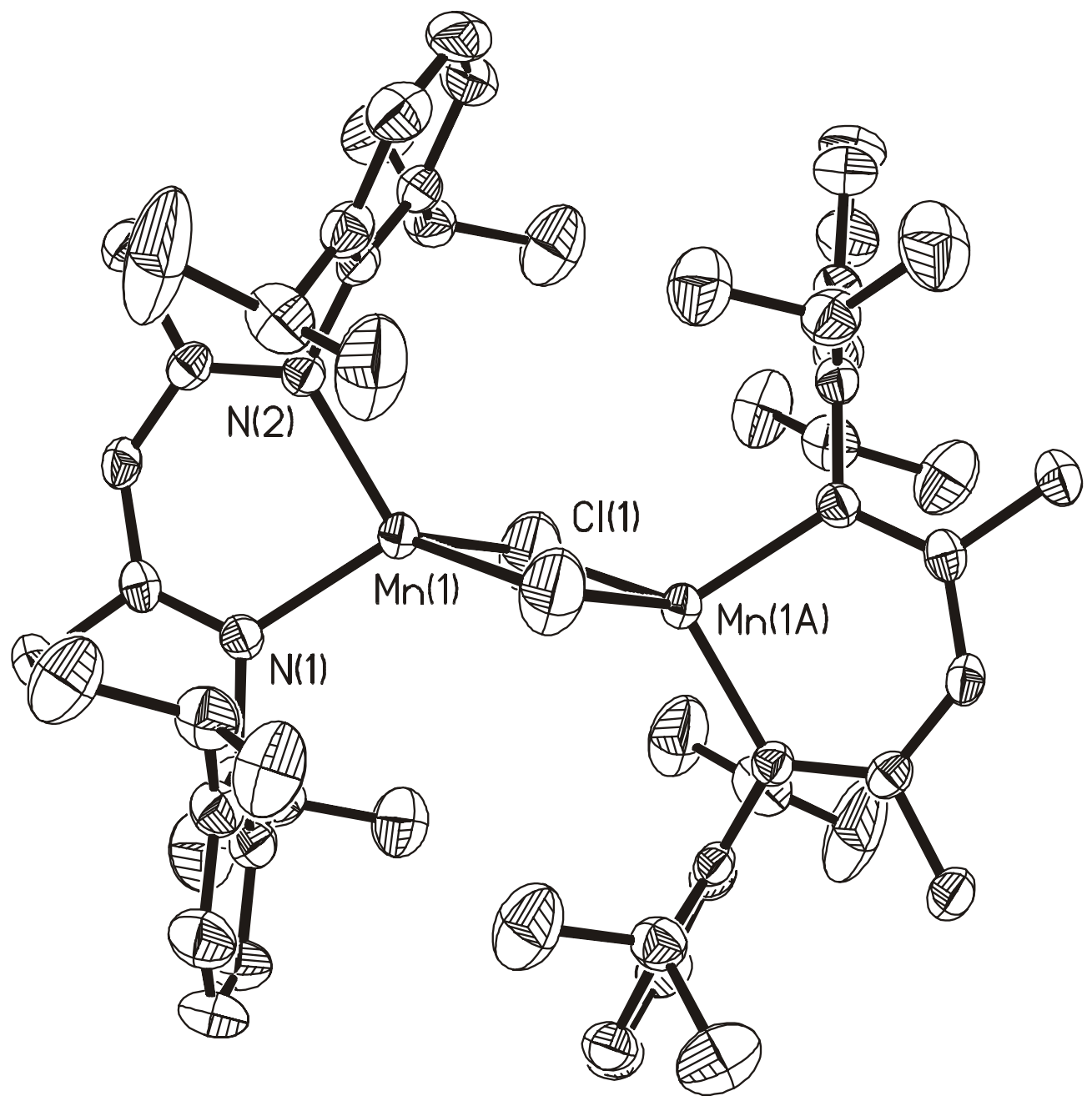

Figure 2. Molecular structure of 4 (50\% probability thermal ellipsoids). Hydrogen atoms are omitted for clarity. 


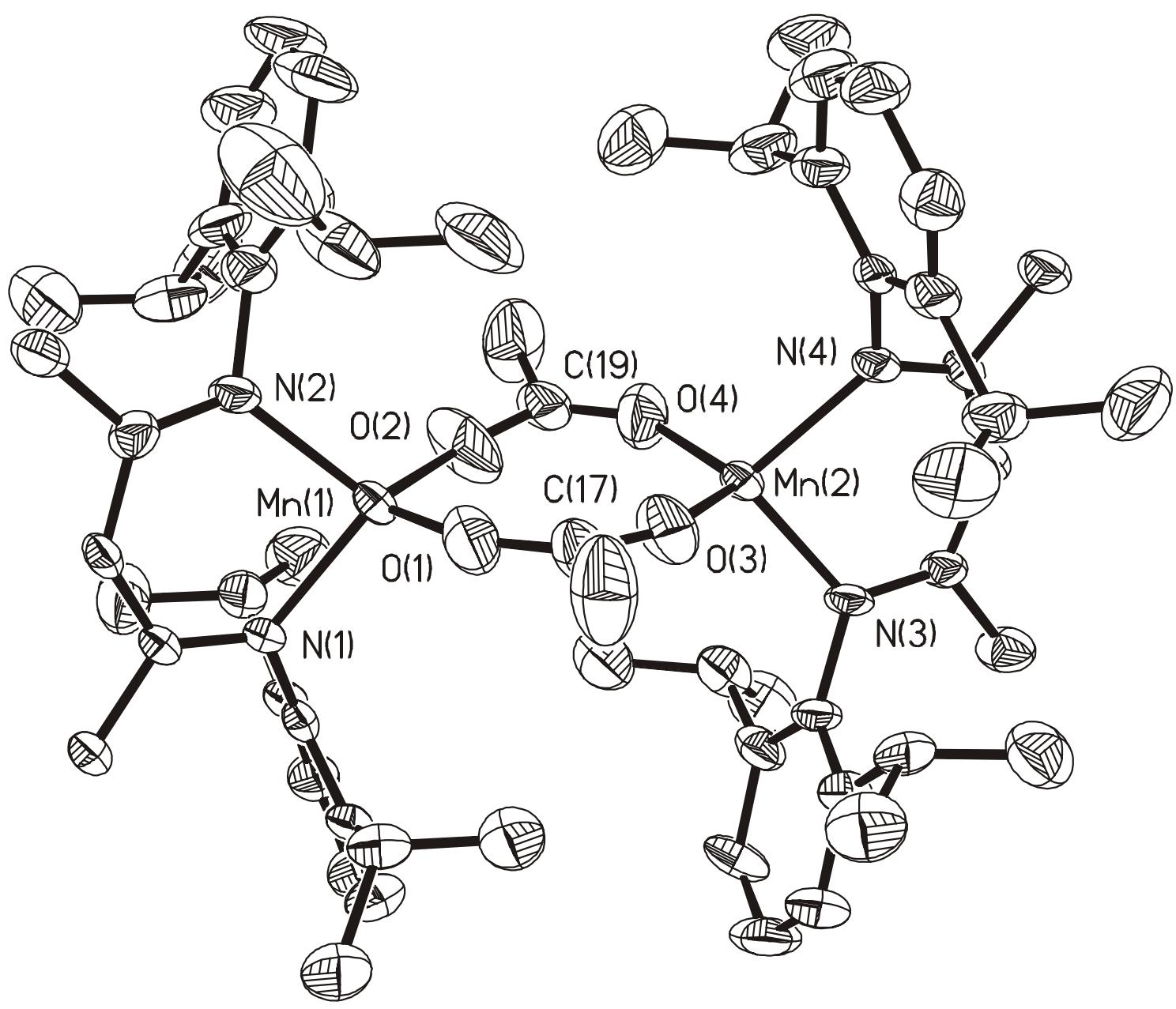

Figure 3. Molecular structure of $\mathbf{5}$ (50\% probability thermal ellipsoids). Hydrogen atoms are omitted for clarity. 


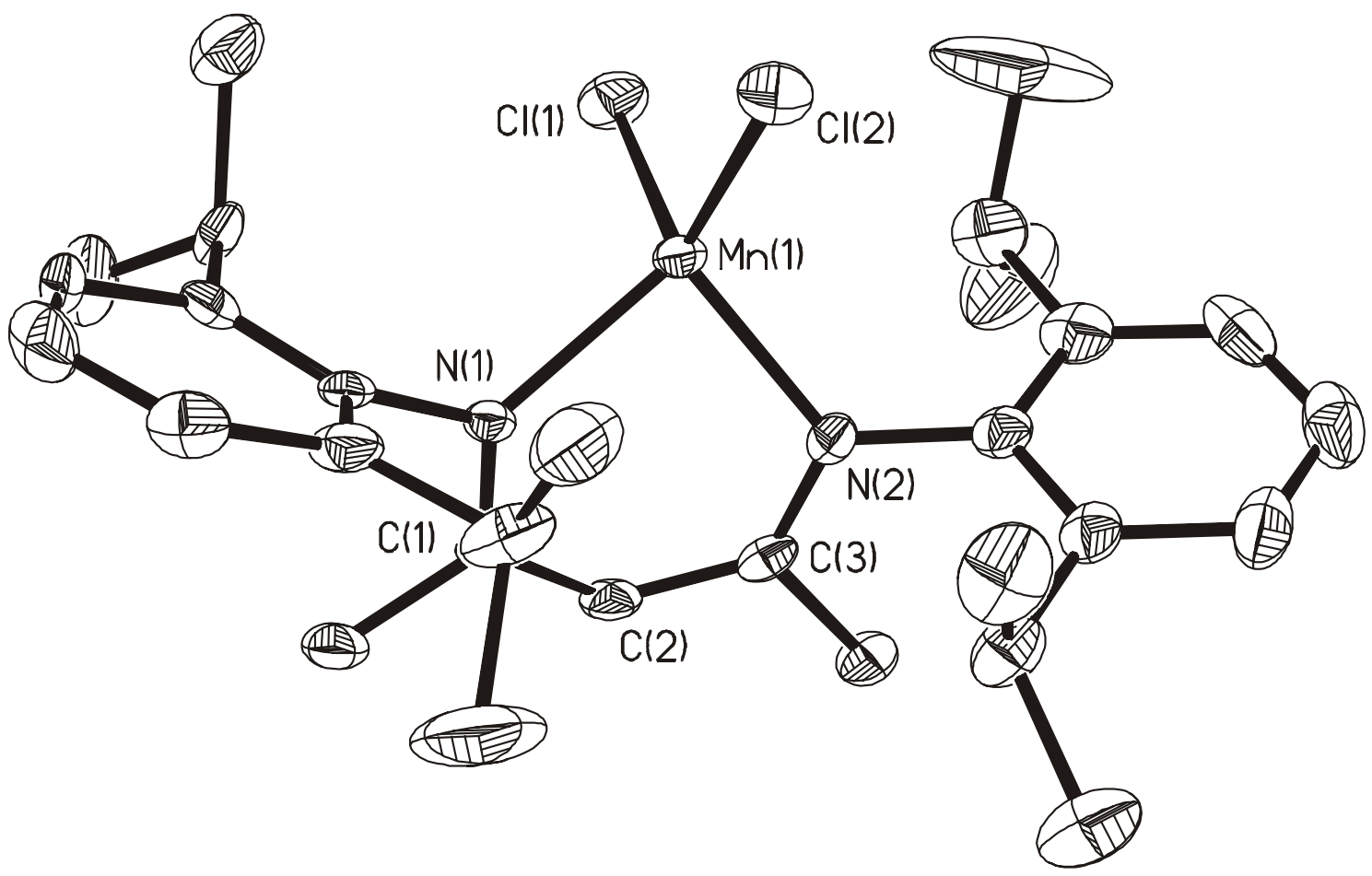

Figure 4. Crystal structure of the anion of 6 (50\% probability thermal ellipsoids). Hydrogen atoms are omitted for clarity. 


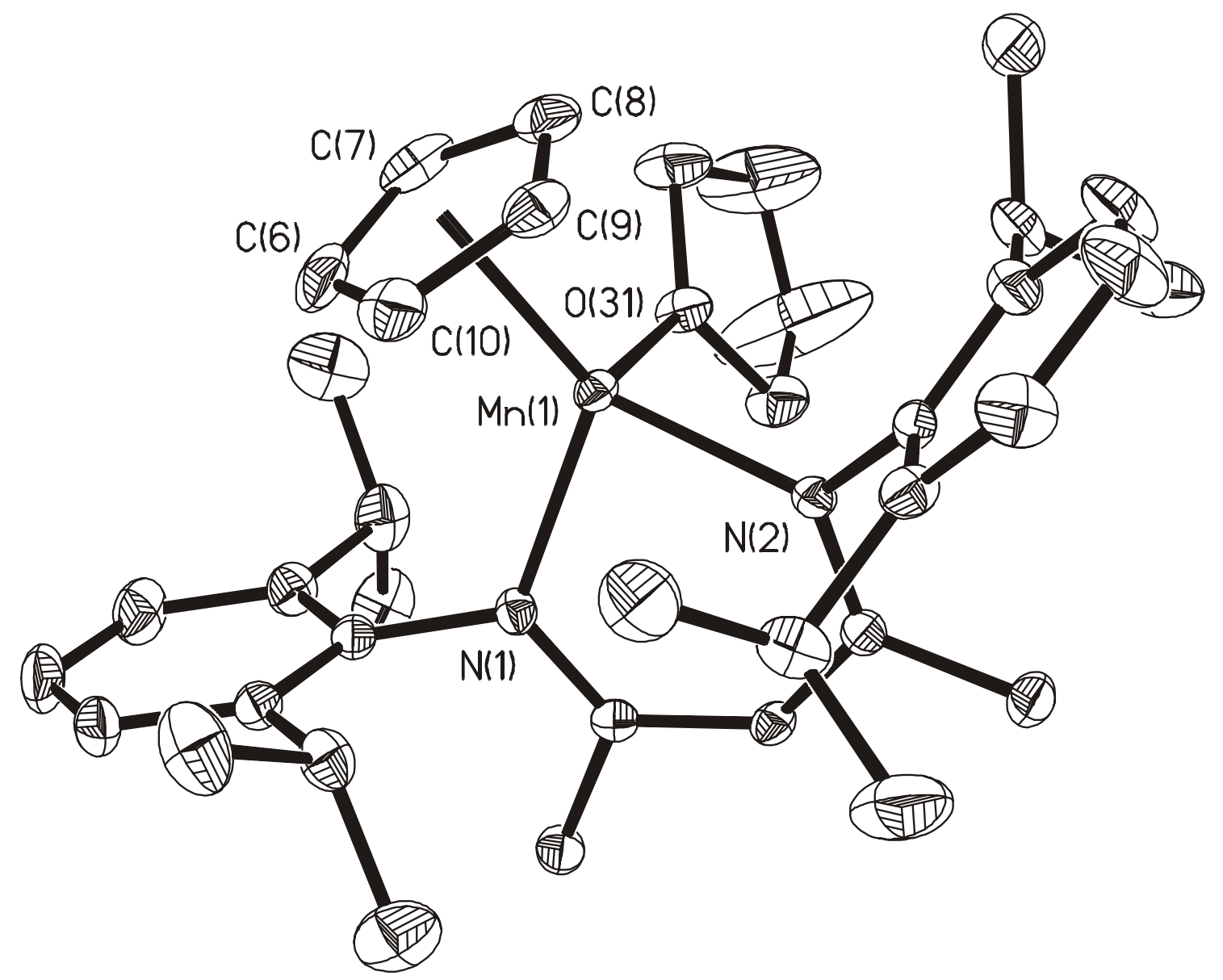

Figure 5. Molecular structure of 7 (50\% probability thermal ellipsoids). Hydrogen atoms are omitted for clarity. 


\section{Content}

A series of neutral and ionic manganese(II) chlorides, as well as a new doubly carboxylatobridged complex containing the bulky $\beta$-diketiminate ligand $\left[\mathrm{HC}(\mathrm{CMeNAr})_{2}\right](\mathrm{Ar}=2,6-$ $\left.i \mathrm{Pr}_{2} \mathrm{C}_{6} \mathrm{H}_{3}\right)$ were synthesized and characterized. In addition, the organomanganese complexes 7-9 were obtained from the reactions of 4 with $\mathrm{CpNa}, \mathrm{MeLi}$, and $\mathrm{PhLi}$, respectively.

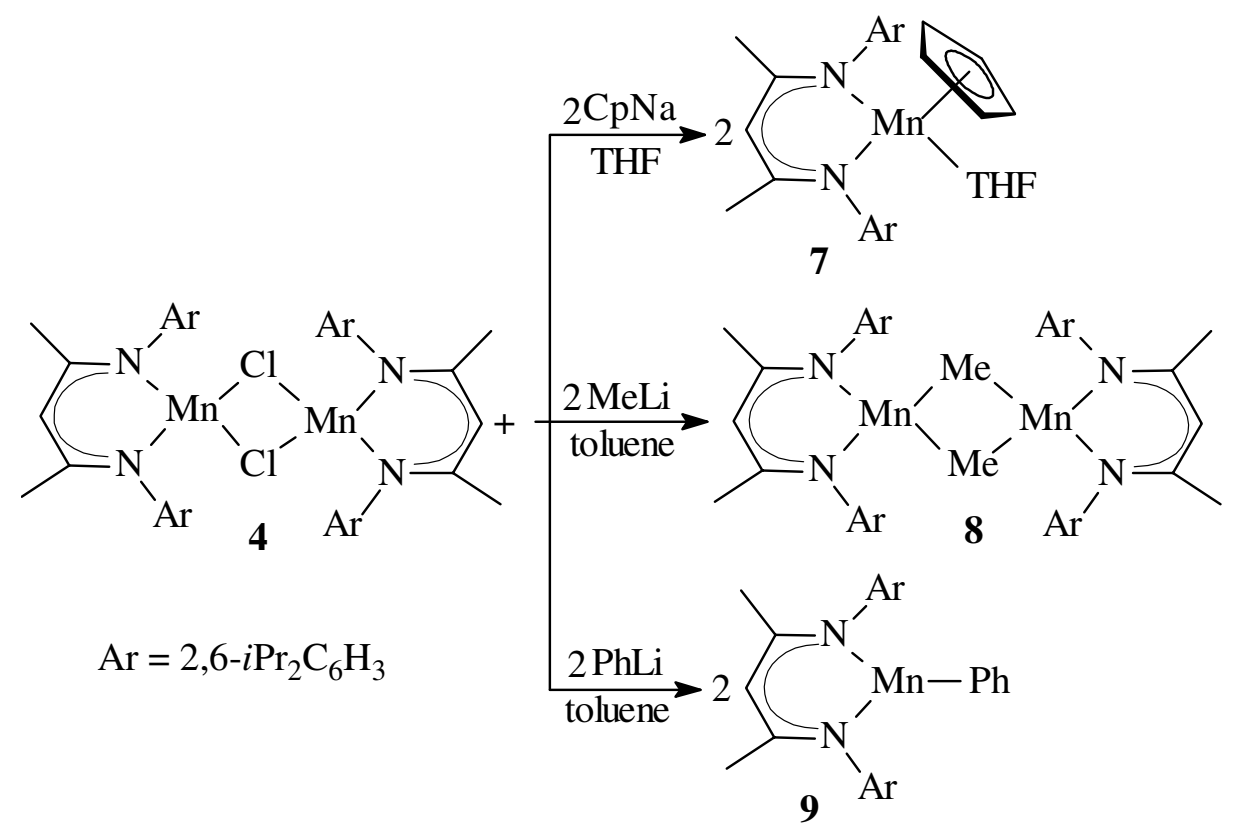

